\title{
Barokinesis and depth regulation by pelagic coral reef fish larvae
}

\author{
Klaus B. Huebert ${ }^{*}$ \\ Division of Marine Biology and Fisheries, University of Miami, RSMAS, 4600 Rickenbacker Causeway, Miami, Florida 33149, USA
}

\begin{abstract}
Vertical distributions of marine fish larvae are of central importance to their ecology, because feeding, predation, and larval transport vary considerably with depth. While numerous studies have characterized vertical distributions of larvae, vertical swimming behavior of individual larvae is poorly understood. In this study, the role of hydrostatic pressure in vertical swimming behavior of pelagic coral reef fish larvae was examined. Larval angelfishes (Pomacanthidae), triggerfishes (Balistidae), surgeonfishes (Acanthuridae), and filefishes (Monacanthidae) were collected in plankton net tows in the Straits of Florida. Tows were vertically stratified with 5 different nets sampling discrete depths up to $100 \mathrm{~m}$. Larvae were individually placed in a hyperbaric chamber and subjected to a sequence of pressure levels simulating depths of up to $66 \mathrm{~m}$ seawater. Larvae from all 4 families showed significant responses, swimming up in response to high pressure and down in response to low pressure. In situ, this barokinetic behavior would cause depth regulation by larvae actively swimming towards 'preferred' pressure levels. Individual pressure preferences were calculated from experimental data and compared to capture depths of the same larvae. Among angelfishes and triggerfishes there was significant correlation between in situ capture depths and experimentally derived pressure preferences, suggesting that the experimental observations resembled natural in situ behavior.
\end{abstract}

KEY WORDS: Fish larvae - Vertical distribution - Behavior - Depth regulation - Barokinesis . Hydrostatic pressure $\cdot$ Coral reef

\section{INTRODUCTION}

The complex life cycle of most coral reef fishes includes a pelagic larval stage. While juveniles and adults are associated with coral reefs, pelagic larvae generally spend weeks to months developing in the open ocean (Leis 1991a). Environmental conditions experienced by larvae during this period are highly variable, and affect larval survival. Mortality rates associated with warm water are particularly high and variable (Houde 1989), and larval transport can differ dramatically, with some larvae being dispersed $>100 \mathrm{~km}$ while others are retained within several $\mathrm{km}$ of their origin (Cowen et al. 2006). Variations in larval survival and transport can profoundly affect the population replenishment of coral reef fishes (Cowen et al. 2000, Bode et al. 2006). Consequently, effective fisheries management and coral reef conservation depend on a thorough understanding of the ecology of pelagic larvae.

The vertical distribution of fish larvae is central to their ecology, since the ocean is vertically stratified with respect to many environmental variables. Both feeding by and predation on larvae depend on several factors that vary with depth, including prey and predator abundance (Fortier \& Harris 1989), light intensity (Job \& Bellwood 2000), and turbulence (Werner et al. 2001). Dispersal of larvae can also be a function of depth if ambient currents are vertically stratified (Paris \& Cowen 2004, Paris et al. 2007). Vertically stratified sampling of coral reef fish larvae has shown that they are not distributed randomly. Leis (1991b) found highly structured family-specific distributions within the upper $20 \mathrm{~m}$ of the Great Barrier Reef lagoon. In oceanic waters off Barbados, taxon- and age-specific vertical 
ranges of tens of meters were observed by Cowen (2002). While it is unclear how these patterns are determined, larval swimming behavior influences vertical distributions in temperate fish larvae (Olla et al. 1996), and reef fish larvae generally swim very fast, with some taxa capable of speeds around $5 \mathrm{~cm} \mathrm{~s}^{-1}$ only $12 \mathrm{~h}$ after hatching (Fisher et al. 2000).

One type of behavior that could influence vertical distributions is barokinesis, or change in swimming activity due to hydrostatic pressure. Barokinetic behavior is exhibited by marine organisms ranging from invertebrate zooplankton (Hardy \& Bainbridge 1951, Park et al. 2004) to fish larvae (Qasim et al. 1963, Macquart-Moulin et al. 1989). In laboratory experiments, increased pressure generally evokes upward swimming (towards lower pressure) and decreased pressure evokes either downward swimming or sinking (towards higher pressure). In nature, this negative feedback mechanism may result in depth regulation and contribute to vertical distributions of barokinetic organisms.

The objectives of the present study were to test whether coral reef fish larvae exhibit barokinesis in experiments and whether the observed behavior is consistent with their swimming depths measured in situ. To simplify the discussion, the term 'larvae' is used in the sense inclusive of all pelagic early life history stages of coral reef fishes. To observe truly pelagic coral reef fish larvae, all experiments were conducted at sea with wild-caught animals collected in plankton net tows. This represents an important departure from previous work that used larvae reared in captivity or collected in light traps over shallow coral reefs. This first attempt to directly compare depths that larvae 'swam towards' in experiments to in situ depths is a quantitative test for barokinesis as a potential mechanism for depth regulation.

\section{MATERIALS AND METHODS}

Collections. Larval coral reef fishes were collected during monthly cruises in the Florida Straits in 2004 and 2005 aboard the University of Miami RV 'F. G. Walton Smith'. The cruises were part of an interdisciplinary study of billfishes, and ichthyoplankton sampling gear and methods were designed specifically for the billfish project. Stratified tows with a coupled asymmetrical MOCNESS (Multiple Opening Closing Net with Environmental Sampling Systems) (Guigand et al. 2005) were conducted with different nets fishing at 0 to 25,25 to 50,50 to 75 , and 75 to $100 \mathrm{~m}$. Additionally, the upper $0.5 \mathrm{~m}$ of the water column was sampled with neuston nets. The duration of MOCNESS tows from $100 \mathrm{~m}$ depth to the surface was $20 \mathrm{~min}$, with each net sampling for $5 \mathrm{~min}$ at a tow speed of $1.5 \mathrm{~m} \mathrm{~s}^{-1}$.
Neuston tows were $10 \mathrm{~min}$ in duration. For a detailed description of sampling locations, see Llopiz \& Cowen (2008). Diurnal samples from MOCNESS nets with a $4 \mathrm{~m}^{2}$ mouth opening and $1 \mathrm{~mm}$ mesh size and neuston nets with a $2 \mathrm{~m}^{2}$ mouth opening and $1 \mathrm{~mm}$ mesh size were inspected for coral reef fish larvae that appeared to be swimming naturally. Each larva was placed in a separate glass cylinder of $9 \mathrm{~cm}$ diameter and $17 \mathrm{~cm}$ height filled with $1 \mathrm{l}$ of seawater on-site and stored in a shaded box until used in experiments.

Experiments. All experiments were conducted at sea; time from specimen collection to onset of the experiment was generally $<4 \mathrm{~h}$ and at most $8 \mathrm{~h}$. At the beginning of an experiment, a cylinder containing a single larva was placed in a 7.51 hyperbaric chamber of the type used for calibrating scuba diving instruments. The chamber was kept dark within the visual spectrum of fishes (Lythgoe 1988), and was illuminated only by an array of infrared LEDs. Larval behavior within the chamber was monitored throughout the experiment with an infrared-sensitive video camera and recorded on tape. Pressure was manipulated by adding air to the chamber from a high-pressure tank and releasing air from the chamber to the atmosphere. Each specimen was tested only once.

The chamber was kept at surface pressure for an acclimation period of $30 \mathrm{~min}$, then pressure was increased by $50 \%$ every $5 \mathrm{~min}$, simulating a stepwise decent from 0 to $5,13,24,41$, and $66 \mathrm{~m}$ depth. This was followed by pressure decreases every 5 min simulating a stepwise ascent from 66 to $41,24,13,5$, and $0 \mathrm{~m}$. Each change was made gradually over the course of 1 min to approximate rates larvae might experience in situ when swimming up or down in the water column at realistic speeds (Leis \& Carson-Ewart 1997). In experiments where the larva clearly behaved similarly under all pressure conditions, the null hypothesis (no barokinesis) was not rejected and the larva was scored as unresponsive. If a larva appeared to change its behavior between different pressure levels, the experiment was continued with additional pressure steps after the original descent and ascent. The additional steps were intended to reduce the chance of incorrectly rejecting the null hypothesis, and increase the accuracy of pressure preference predictions. In some experiments, the acclimation period, individual time steps, or the sequence of pressure levels deviated from the described protocol due to logistical constraints at sea. Seven experiments were ended when erratic or unnatural swimming behavior became evident (Fisher et al. 2000). This occurred when larvae became too weak to overcome positive buoyancy at low pressures by downward swimming. Three larvae were used in pressure experiments after first being exposed to a series of different light intensities for a related study. 
Analysis. Videotapes were digitized and visual reference grids, numbered from 1 at the bottom of the cylinder to 10 at the water surface, were superimposed on each image (Fig. 1). Vertical positions of each larva relative to this grid were recorded every $10 \mathrm{~s}$. Only observations made at constant pressure were included in data analysis; data points during transitions between time steps were discarded. Preliminary analysis revealed that significant autocorrelation was present during some time steps, affecting up to 3 data points or $30 \mathrm{~s}$ duration. To eliminate this problem and ensure independent data points, subsamples of 100 data points were used in all further analyses.

Behavioral data did not conform to the assumptions of parametric statistics, so the relationship between larval behavior and pressure was determined using resampling methods. Pearson's correlation coefficient (r) between larval vertical position and pressure was bootstrapped and the significance of the correlation was determined by a permutation test (Hesterberg et al. 2005). If 1000 bootstrapped r-values exceeded

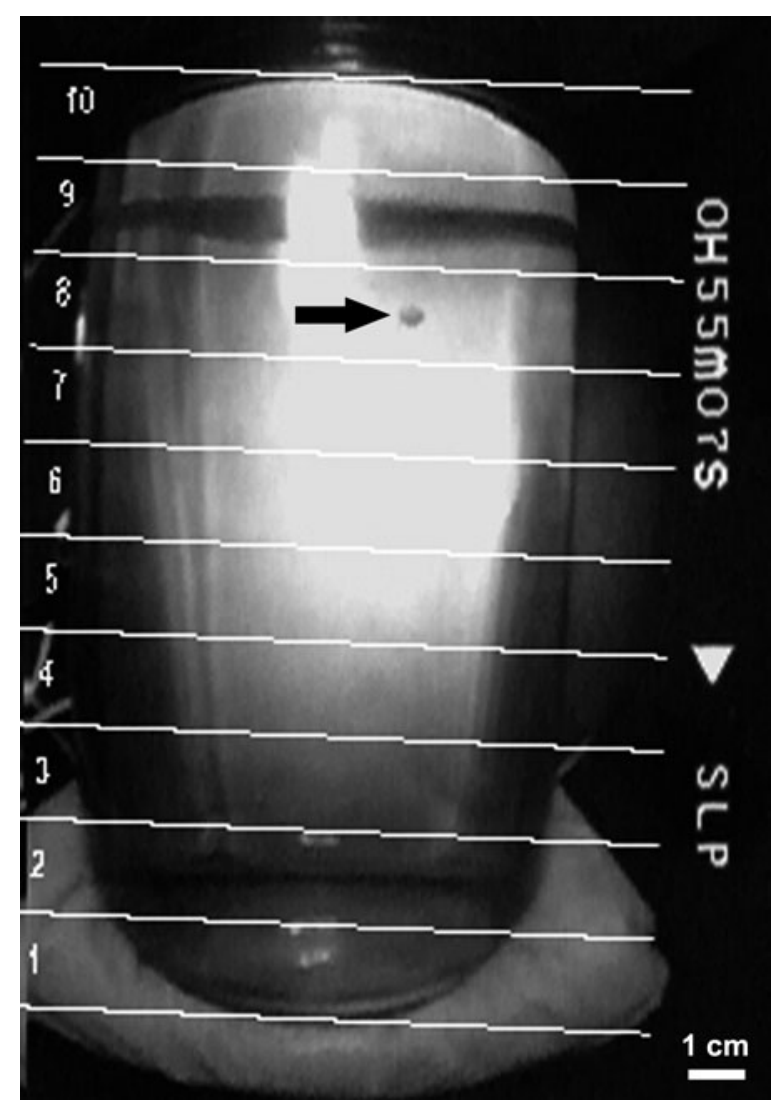

Fig. 1. Larva swimming in glass cylinder inside a hyperbaric chamber. Larval behavior was recorded in darkness with an infrared camera. The superimposed grid was used to score vertical positions; here the larva is at position 8. Grid is slanted to correct for camera angle
1000 permuted r-values in at least $95 \%$ of pairwise comparisons, the correlation was considered significant $(\mathrm{p}<0.05)$. Since pressure was an independent variable by experimental design, significant correlation revealed that position was dependent on pressure. In this case, 1000 bootstrapped linear regression parameters (slope and intercept) were used to predict the mean pressure at which the mean larval position would be at the center of the cylinder, with no net vertical movement. These 'pressure preferences' are estimates for the depth that larvae 'swam towards' in experiments, and sometimes exceeded the 0 to $66 \mathrm{~m}$ pressure range at which larvae had been observed. For example, a mean position of 2 (near the bottom) at $41 \mathrm{~m}$, and 4 (slightly beneath center) at $66 \mathrm{~m}$ would result in a pressure preference (position 5.5) of $85 \mathrm{~m}$. The effectiveness of predicting in situ behavior from experimental data was determined by a permutation test of the correlation between capture depth and pressure preference within each family. Uncertainty in the capture depth of larvae within the vertical range of plankton net tows was included by randomly generating depths within the appropriate ranges using a uniform distribution. If the correlation was significant, a bootstrapped regression was performed (as explained above), to model capture depths with pressure preferences. All statistical analyses were conducted using S-Plus (Insightful).

\section{RESULTS}

Experiments were conducted with 14 larvae of the family Pomacanthidae (angelfishes), 9 Balistidae (triggerfishes), 12 Acanthuridae (surgeonfishes), and 21 Monacanthidae (filefishes). Most larvae could not be identified beyond family, therefore only results of individual experiments and of experiments pooled by family are presented. Larvae ranged in size from 3.4 to $19.6 \mathrm{~mm}$ standard length, and included specimens of various developmental stages.

In 34 of 56 experiments, there was significant positive correlation between larval vertical position and hydrostatic pressure (permutation test: $\mathrm{p}<0.05$ ) (Table 1). Broken down by family, 11 of 14 pomacanthids, 8 of 9 balistids, 9 of 12 acanthurids, and 6 of 21 monacanthids moved down during low pressure (shallow depth) steps and up during high pressure (deep depth) steps (Fig. 2). Note that changes in swimbladder buoyancy caused by pressure changes would result in the opposite pattern, whereas the observed positive correlation can only be due to barokinesis. Sometimes larvae encountered the top or bottom surface of the water column and continued to energetically swim 'against' this surface. At other times they 
Table 1. Significant responses in larval vertical position to absolute pressure stimuli (bold). Larvae were collected in plankton nets towed at known depth ranges (capture depth). The pressure that each larva 'swam towards' was calculated from experimental data (pressure preference and 95\% confidence interval). Significance was determined by permutation test. ns $=$ not significant

\begin{tabular}{|c|c|c|c|c|c|}
\hline $\begin{array}{l}\text { Family and } \\
\text { fish number }\end{array}$ & $\begin{array}{l}\text { Standard } \\
\text { length } \\
\text { (mm) }\end{array}$ & $\begin{array}{l}\text { Capture } \\
\text { depth } \\
\text { (m) }\end{array}$ & $\begin{array}{c}\text { Response } \\
\mathrm{R}^{2} \\
\mathrm{p}<0.05\end{array}$ & $\begin{array}{l}\text { Pressure } \\
\text { preference } \\
(\mathrm{m})\end{array}$ & $\begin{array}{l}95 \% \\
\mathrm{CI} \\
(\mathrm{m})\end{array}$ \\
\hline \multicolumn{6}{|c|}{ Pomacanthidae } \\
\hline P-1 & 6.7 & 0 to 25 & 0.08 & 15 & 8 to 30 \\
\hline P-2 & 9.6 & 0 to 25 & 0.61 & 47 & 42 to 52 \\
\hline P-3 & 19 & 0 to 25 & ns & - & - \\
\hline $\mathrm{P}-4^{\mathrm{a}}$ & 5.3 & 25 to 50 & ns & - & - \\
\hline P-5 & 7.1 & 25 to 50 & 0.34 & 13 & 10 to 16 \\
\hline P-6 & 9.9 & 25 to 50 & 0.30 & 22 & 18 to 27 \\
\hline P-7 & 15.1 & 25 to 50 & 0.55 & 46 & 42 to 51 \\
\hline P-8 & 5.9 & 50 to 75 & 0.33 & 50 & 43 to 61 \\
\hline P-9 & 6.2 & 50 to 75 & $\mathrm{~ns}$ & - & - \\
\hline P-10 & 6.4 & 50 to 75 & 0.22 & 68 & 53 to 90 \\
\hline P-11 & 6.5 & 50 to 75 & 0.49 & 63 & 55 to 74 \\
\hline P-12 & 7.7 & 50 to 75 & 0.10 & 65 & 44 to 106 \\
\hline P-13 & 9.7 & 75 to 100 & 0.50 & 64 & 54 to 80 \\
\hline P-14 & 14.5 & 75 to 100 & 0.37 & 62 & 53 to 75 \\
\hline \multicolumn{6}{|l|}{ Balistidae } \\
\hline $\mathrm{B}-1^{\mathrm{a}}$ & 4 & neuston & 0.36 & 16 & 9 to 22 \\
\hline B-2 & 6.1 & neuston & 0.28 & 10 & 7 to 14 \\
\hline B-3 & 6.2 & neuston & 0.35 & 8 & 6 to 9 \\
\hline B-4 & 11.9 & neuston & ns & - & - \\
\hline $\mathrm{B}-5^{\mathrm{a}}$ & 3.4 & 0 to 25 & 0.19 & 52 & 43 to 66 \\
\hline $\mathrm{B}-6^{\mathrm{a}}$ & 4.5 & 0 to 25 & 0.31 & 71 & 60 to 87 \\
\hline B-7 & 6.1 & 0 to 25 & 0.44 & 21 & 17 to 25 \\
\hline B-8 & 6.2 & 25 to 50 & 0.52 & 45 & 38 to 53 \\
\hline B-9 & 14.4 & 75 to 100 & 0.40 & 72 & 63 to 87 \\
\hline \multicolumn{6}{|l|}{ Acanthuridae } \\
\hline A-1 $1^{b}$ & 4 & 0 to 25 & 0.40 & 85 & 63 to 123 \\
\hline $\mathrm{A}-2^{\mathrm{b}}$ & 4.9 & 0 to 25 & 0.28 & 53 & 41 to 58 \\
\hline A-3 & 7.4 & 0 to 25 & ns & - & - \\
\hline A-4 & 8.2 & 0 to 25 & 0.07 & 170 & 115 to 394 \\
\hline A-5 & 15.9 & 0 to 25 & 0.15 & 70 & 53 to 96 \\
\hline A-6 & 5.3 & 25 to 50 & 0.11 & 229 & 147 to 363 \\
\hline A-7 & 5.3 & 25 to 50 & 0.49 & 8 & 7 to 9 \\
\hline A-8 & 6.5 & 25 to 50 & 0.14 & 15 & 9 to 25 \\
\hline A-9 & 8.2 & 25 to 50 & 0.59 & 12 & 10 to 13 \\
\hline A-10 & 16.7 & 25 to 50 & ns & - & - \\
\hline A-11 & 15.3 & 75 to 100 & ns & - & - \\
\hline A-12 & 16.2 & 75 to 100 & 0.33 & 57 & 45 to 74 \\
\hline \multicolumn{6}{|l|}{ Monacanthidae } \\
\hline M-1 & 7 & 0 to 25 & ns & - & - \\
\hline $\mathrm{M}-2$ & 7.3 & 0 to 25 & 0.14 & 137 & 90 to 225 \\
\hline$M-3^{a}$ & 7.9 & 0 to 25 & 0.22 & 100 & 73 to 146 \\
\hline M-4 & 8 & 0 to 25 & 0.25 & 63 & 52 to 80 \\
\hline M-5 & 8.2 & 0 to 25 & 0.25 & 37 & 30 to 49 \\
\hline M-6 & 9.5 & 0 to 25 & ns & - & - \\
\hline M-7 & 9.8 & 0 to 25 & ns & - & - \\
\hline$M-8^{a}$ & 10.7 & 0 to 25 & ns & - & - \\
\hline M-9 & 10.8 & 0 to 25 & ns & - & - \\
\hline M-10 & 10.9 & 0 to 25 & ns & - & - \\
\hline $\mathrm{M}-11^{\mathrm{a}}$ & 6.2 & 25 to 50 & 0.33 & 6 & -1 to 10 \\
\hline M-12 & 7.7 & 25 to 50 & ns & - & - \\
\hline M-13 & 9.8 & 25 to 50 & ns & - & - \\
\hline M-14 & 9.9 & 25 to 50 & $\mathrm{~ns}$ & - & - \\
\hline M-15 & 12.5 & 25 to 50 & 0.30 & 66 & 52 to 90 \\
\hline M-16 & 14.1 & 25 to 50 & ns & - & - \\
\hline M-17 & 9.8 & 50 to 75 & ns & - & - \\
\hline M-18 & 12.1 & 50 to 75 & $\mathrm{~ns}$ & - & - \\
\hline$M-19^{b}$ & 14.9 & 50 to 75 & ns & - & - \\
\hline M-20 & 19.6 & 50 to 75 & ns & - & - \\
\hline M-21 & 17.9 & 75 to 100 & ns & - & - \\
\hline
\end{tabular}

avoided the top and bottom surfaces, swimming mostly in the lower half of the cylinder during low-pressure steps and making increasingly frequent excursions into the upper half during higher-pressure steps. In a real ocean water column this behavior would cause larvae to move towards a particular depth range.

Significant positive correlation (permutation test: $\mathrm{p}<0.05$ ) between pressure preference and in situ capture depth was present in the families Pomacanthidae and Balistidae, but not in Acanthuridae, Monacanthidae, or with all families combined. Pressure preference explained almost half of the variance in capture depth in regression models of pomacanthids $\left(\mathrm{R}^{2}=0.47\right)$ and balistids $\left(\mathrm{R}^{2}=0.45\right)$ (Fig. 3$)$. Most pressure preferences fell within the 0 to $66 \mathrm{~m}$ range at which experiments were conducted. Pressure preference values $>66 \mathrm{~m}$ reflect experiments where the mean position of larvae in the experimental cylinder increased with depth, but did not exceed the center, position 5.5. In 2 acanthurid and 2 monacanthid experiments, pressure preferences exceeded the 0 to $66 \mathrm{~m}$ range to such an extent that even the lower boundaries of $95 \%$ confidence intervals were $>66 \mathrm{~m}$. These outliers are suspect, because they were calculated by regression on data at pressures $<66 \mathrm{~m}$, but their inclusion did not change the results of the preceding statistical analyses.

\section{DISCUSSION}

Larvae from all 4 families (Pomacanthidae, Balistidae, Acanthuridae, and Monacanthidae) varied their vertical swimming behavior significantly across different levels of hydrostatic pressure. This indicates a sense of pressure, which has previously been found in a variety of adult and larval fishes, but not in coral reef fish larvae. In adults, pressure sensitivity has been demonstrated by reflexive 'yawning' responses (McCutcheon 1966), by conditioning fish to associate pressure changes with food (Dijkgraaf 1941) or electric 


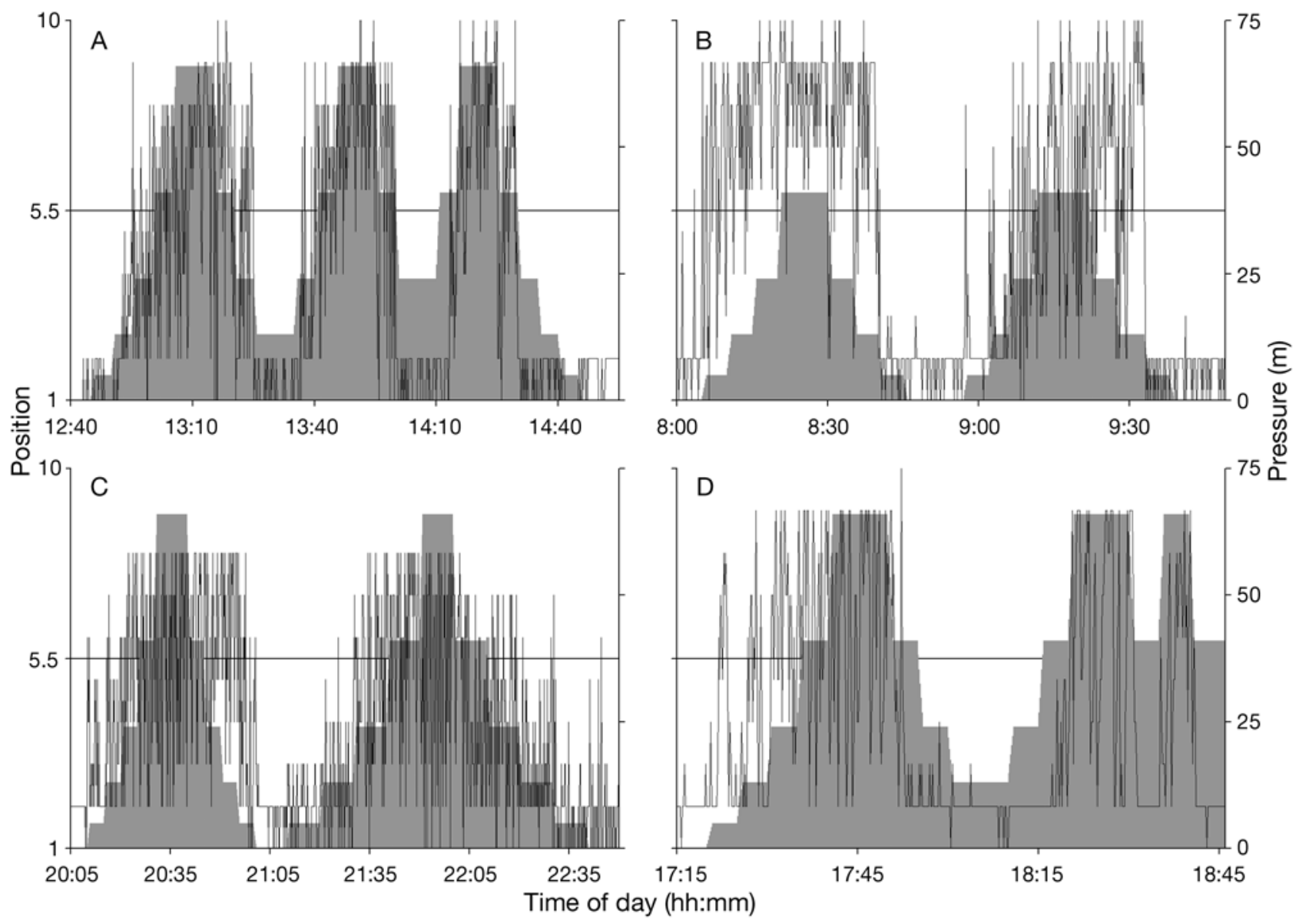

Fig. 2. Sample data of experiments with (A) pomacanthid P-2, (B) balistid B-7, (C) acanthurid A-12, and (D) monacanthid M-4. Area: pressure (corresponding water depth, $\mathrm{m}$ ); line: larval position. At onset of experiment, larvae were under surface pressure and swam down. Larvae increasingly swam up at higher pressure then down again at lower pressure. At the calculated pressure preference there was minimal net movement relative to center of the cylinder, position 5.5

shocks (Tytler \& Blaxter 1973), and by electrophysiological recordings (Koshtojanz \& Vassilenko 1937). In larvae, pressure sensitivity has been demonstrated by swimbladder inflation (Govoni \& Hoss 2001) and barokinesis (Qasim et al. 1963). Thresholds for pressure sensitivity are generally on the order of $1 \%$ of absolute ambient pressure, for example $0.1 \mathrm{~m}$ at the surface or $1 \mathrm{~m}$ at $90 \mathrm{~m}$ depth. Sensory mechanisms of pressure sensitivity remain unclear in most fishes. Movements resulting from changes in buoyancy are presumably detected by neuromasts in the vestibular system and the developing lateral line system. In the absence of movement, Weberian ossicles (Dijkgraaf 1941) and neuroreceptors in the swimbladder (Koshtojanz \& Vassilenko 1937) can convey pressure sensitivity, and even fishes lacking these structures can sense pressure (Qasim et al. 1963). In sharks, vestibular neuromasts in the labyrinth convey absolute hydrostatic pressure information (Fraser \& Shelmerdine 2002).
This system may exist in teleost fishes as well. While pressure sensitivity studies in fishes have historically focused on sensory biology, the present study was concerned with the ecology of pressure-mediated behavior.

Coral reef fish larvae exhibited similar barokinetic behavior to other larval fishes, in that they moved up in response to high pressure and down in response to low pressure. However, previous studies were inconclusive with respect to the potential for depth regulation. Macquart-Moulin et al. (1989) demonstrated barokinesis in sole larvae during and immediately following pressure changes of $1 \mathrm{~m}$, but the behavior was too short-lived to effectively regulate depth. Qasim et al. (1963) reported that groups of blenny, gunnel, and flounder larvae moved back and forth between the lower and upper half of a pressure vessel in response to sudden changes between $0 \mathrm{~m}$ and 6 to $10 \mathrm{~m}$ pressure. Depth regulation seems likely, but absolute pres- 


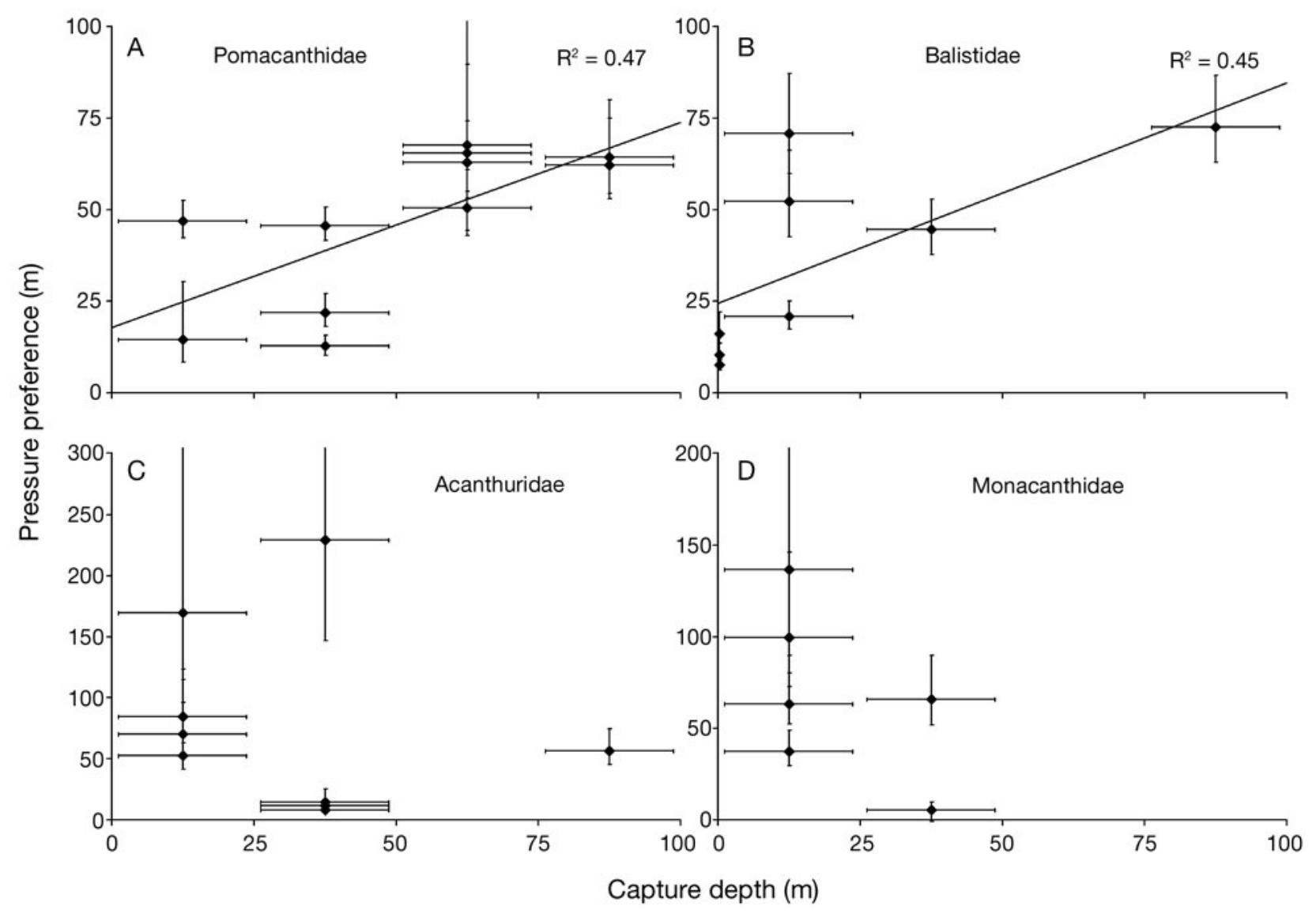

Fig. 3. In situ capture depths and experimentally derived pressure preferences of all larvae exhibiting barokinesis in (A) Pomacanthidae, (B) Balistidae, (C) Acanthuridae, and (D) Monacanthidae. Capture depth ranges are $95 \%$ of the vertical ranges of net tows; pressure preference ranges represent $95 \%$ confidence intervals. Regression model indicated by line in $(A, B)$

sure $(6 \mathrm{~m})$, pressure change $(60 \%)$, and rate of pressure change $(60 \%$ in only a few seconds) were confounded as potential cues. In the present study, the confounding effects of absolute pressure, pressure change, and rate of pressure change were minimized by design. Pressure steps were spaced at even $50 \%$ increases, changes were gradual, and data recorded during changes were excluded. Finally, larvae were observed at the same absolute pressure levels following changes from both directions. With all this taken into account, pressure often explained a considerable fraction of vertical swimming behavior, with larvae moving up at high pressures (corresponding to deep depths) and down at low pressures (corresponding to shallow depths). Beyond demonstrating the mere possibility of depth regulation, the results presented here show that barokinesis can be important in structuring vertical distributions of larval coral reef fishes.

Significant correlation between pressure preference and capture depth in pomacanthids and balistids refutes the null hypothesis that behavior in experiments and behavior in situ were unrelated. Almost half of the variance in capture depth was successfully predicted by the regression model $\left(\mathrm{R}^{2}=0.47\right.$ for pomacanthids and $\mathrm{R}^{2}=0.45$ for balistids), which provides circumstantial evidence for a cause-effect relationship between barokinesis and depth regulation in situ. Nevertheless, the precision with which individual capture depths could be predicted was low. This is reflected in the number of experiments where pressure preferences matched the capture net tow depth ranges. Of 14 pomacanthids, 6 had pressure preferences within the depth range of the net tow in which they were collected, 5 had pressure preferences 0 to 25 m outside their capture depth range, and 3 had no significant pressure preferences. Of 9 balistids, 2 had pressure preferences within the correct depth range, 4 had pressure preferences 0 to $25 \mathrm{~m}$ outside the capture depth range, 2 had pressure preferences 25 to $50 \mathrm{~m}$ outside the capture depth range, and 1 had no significant pressure preference. One possible explanation is that in nature, barokinesis influences depth regulation on a relatively coarse scale (10s of $\mathrm{m})$, while other factors are more important at a finer scale. For example, some 
pelagic reef fish larvae seek out structures such as flotsam, drifting algae, or jellyfish (Kingsford 1993). This might also explain why pressure preference and capture depth were unrelated in monacanthids, which are strongly associated with drifting algae (Kingsford 1992). Alternatively, barokinesis may act on a much finer spatial scale in nature than could be resolved in experiments. Vertical distributions of coral reef fish larvae are known to change on diel cycles (Leis 1991b), and any change in depth-regulating behavior during the hours between sampling and experiment would have weakened the relationship between capture depth and pressure preference. This possibly explains why pressure preference and capture depth were unrelated in acanthurids and monacanthids, despite significant barokinetic behavior at the individual level.

Despite examples of barokinesis in all 4 families, several larvae were unresponsive in experiments, revealing limitations in the chosen methodology. First, all larvae were exposed to physical and biological stress during the collection process. Great care was taken to exclude injured larvae, but mechanical abrasion against the net and predator-prey interactions within the sample may have led to unnatural behavior. Second, the small experimental cylinder and externally applied pressure changes could have triggered escape responses, masking natural behavior. Third, pressure is only one of several variables conveying information related to depth. For example, keeping the hyperbaric chamber dark at all times disrupted the natural relationship between pressure and light at depth. The presence of an air-water interface at the top of the cylinder also conflicted with pressure cues, indicating a depth very near the surface at all times. Contradictions between different environmental stimuli in controlled laboratory conditions can disrupt natural orientation behavior (Pavlov et al. 2000). Despite these complications, most larvae exhibited significant pressure preferences, suggesting that the ability to regulate depth by barokinesis is common among pelagic reef fish larvae and, presumably, other fishes as well.

Since the in situ depths of pomacanthid and balistid larvae could be predicted by experiments, it is tempting to also draw inferences about larval populations. This requires additional care because sampling was strongly biased towards larvae of large size, high condition, shallow depth, or otherwise likely to survive net tows. Therefore, sample statistics are not necessarily representative of larval populations. One statistic that is a conservative estimate for the population is the range of pressure preferences within families. Pressure preferences of pomacanthids and balistids varied in accordance with in situ depths over a vertical range of tens of meters. This requires a substantial degree of behavioral plasticity, with different larvae from the same population exhibiting distinct barokinetic behavior. In fact, plasticity in barokinesis alone may account for the entire vertical range of reef fish larvae, which is limited to only tens of meters in various families in the study area (Cha et al. 1994). Another finding with implications at the population level is the timescale of several hours across which pressure preferences and capture depths were correlated in pomacanthids and balistids. If the vertical behavior of individual larvae is persistent and they occupy narrow depth ranges in situ at this timescale, vertical distributions could be quite stable throughout the day. Acanthurid and monacanthid distributions, on the other hand, may be more dynamic. These ideas can be used to refine or test models of recruitment variability and larval transport (Cowen et al. 2006), which are becoming increasingly important in the management of fisheries (Sale et al. 2005, Fogarty \& Botsford 2007).

The proposed role of barokinesis as a proximate mechanism for depth regulation does not imply that the ultimate function of depth regulation is related to hydrostatic pressure. In fact, other environmental variables are clearly more important. Vertical distributions of predators and prey have immediate consequences for larval survival (Fortier \& Harris 1989). The vertical gradient of light limits larvae to shallow depths, where they can feed effectively (Job \& Bellwood 2000) but the risk of detection by predators is increased (Bailey \& Houde 1989). Turbulence affects predator-prey interactions by increasing encounter rates (Rothschild \& Osborn 1988) while decreasing successful capture rates (MacKenzie \& Kiorboe 2000). Finally, the vertical distribution of ambient water current influences physical transport (Paris \& Cowen 2004, Paris et al. 2007), which is essential for larval survival (Pineda et al. 2007). In contrast, larval ecology does not appear to depend much on pressure. Pressure mainly affects buoyancy, and perciform larvae should be able to regulate their swimbladder volume to compensate for pressure changes starting around the time of yolk-sac depletion and first feeding (Pelster 2004). Govoni \& Hoss (2001) confirmed this experimentally in spot, reporting that late-stage larvae could compensate within an hour for negative buoyancy caused by a $10 \mathrm{~m}$ pressure increase. Similar swimbladder adjustments were also apparent in the present study. More importantly, larvae were able to compensate for improper buoyancy by vertical swimming, which is energetically more expensive but much faster (Strand et al. 2005). If non-neutral buoyancy is easily overcome, then no particular pressure level is inherently favorable for larval survival. This points towards the use of pressure as a proxy for something else. The relationship between 
the proximate cue pressure and the ultimate cause of depth regulation is unclear, but any cue correlated with feeding, predator avoidance, and larval transport might be exploited to enhance survival. While it is not a trivial problem to unravel the fundamental causeeffect relationships, depth regulation and vertical distributions of fish larvae play a major role in determining these processes.

Acknowledgements. Financial support was provided by NSF Grant No. OCE-0136132 to R. Cowen, S. Sponaugle, S. Smith, K. Leaman, D. Olson, and J. Serafy and a Robert Maytag Fellowship to K.H. Methods were approved in University of Miami Animal Care and Use Committee protocols 05-019 and 05-134. Many thanks to S. Sponaugle for advice, encouragement, and direction at every stage of the project. $\mathrm{R}$. Cowen made the study possible by providing space and support during billfish project cruises. J. Llopiz and D. Richardson patiently identified larvae. Hypotheses and experimental design were refined in collaboration with A. Myrberg. R. Gomez provided the hyperbaric chamber and C. Guigand and T. Snowdon helped with electronics. The captain and crew of the RV 'F. G. Walton Smith' assisted in various ways at sea. C. Harper helped with video processing and K. GrorudColvert helped with length measurements. Discussions with J. Serafy, J. Hare, and M. Schmale informed the data analysis and presentation. Early drafts of the manuscript were greatly improved upon thanks to comments by S. Sponaugle, R. Cowen, J. Hare, J. Serafy, T. Rankin, L. Zamora, and 3 anonymous reviewers.

\section{LITERATURE CITED}

Bailey KM, Houde ED (1989) Predation on eggs and larvae of marine fishes and the recruitment problem. Adv Mar Biol 25:1-83

Bode M, Bode L, Armsworth PR (2006) Larval dispersal reveals regional sources and sinks in the Great Barrier Reef. Mar Ecol Prog Ser 308:17-25

Cha SS, Mcgowan MF, Richards WJ (1994) Vertical distribution of fish larvae off the Florida Keys, 26 May-5 June 1989. Bull Mar Sci 54:828-842

Cowen RK (2002) Larval dispersal and retention and consequences for population connectivity. In: Sale PF (ed) Coral reef fishes. Academic Press, San Diego, CA, p 149-170

Cowen RK, Lwiza KMM, Sponaugle S, Paris CB, Olson DB (2000) Connectivity of marine populations: Open or closed? Science 287:857-859

Cowen RK, Paris CB, Srinivasan A (2006) Scaling of connectivity in marine populations. Science 311:522-527

Dijkgraaf S (1941) Über die bedeutung der weberschen knöchel für die wahrnehmung von schwankungen des hydrostatischen druckes. Z Vgl Physiol 28:389-401

Fisher R, Bellwood DR, Job SD (2000) Development of swimming abilities in reef fish larvae. Mar Ecol Prog Ser 202:163-173

Fogarty MJ, Botsford LW (2007) Population connectivity and spatial management of marine fisheries. Oceanography 20:112-123

Fortier L, Harris RP (1989) Optimal foraging and densitydependent competition in marine fish larvae. Mar Ecol Prog Ser 51:19-33

Fraser PJ, Shelmerdine RL (2002) Fish physiology - dogfish hair cells sense hydrostatic pressure. Nature 415:495-496
Govoni JJ, Hoss DE (2001) Comparison of the development and function of the swimbladder of Brevoortia tyrannus (Clupeidae) and Leiostomus xanthurus (Sciaenidae). Copeia 2001:430-442

Guigand CM, Cowen RK, Llopiz JK, Richardson DE (2005) A coupled asymmetrical multiple opening closing net with environmental sampling systems. Mar Technol Soc J 39: $22-24$

> Hardy AC, Bainbridge R (1951) Effect of pressure on the behaviour of decapod larvae (Crustacea). Nature 167: 354-355

Hesterberg T, Moore DS, Monaghan S, Clipson A, Epstein R (2005) Bootstrap methods and permutation tests. In: Moore DS, McCabe GP (eds) Introduction to the practice of statistics. W.H. Freeman \& Company, New York

Houde ED (1989) Comparative growth, mortality, and energetics of marine fish larvae: temperature and implied latitudinal effects. Fish Bull 87:471-495

Job SD, Bellwood DR (2000) Light sensitivity in larval fishes: implications for vertical zonation in the pelagic zone. Limnol Oceanogr 45:362-371

> Kingsford MJ (1992) Drift algae and small fish in coastal waters of northeastern New Zealand. Mar Ecol Prog Ser 80:41-55

Kingsford MJ (1993) Biotic and abiotic structure in the pelagic environment: importance to small fishes. Bull Mar Sci 53:393-415

Koshtojanz CS, Vassilenko PD (1937) On the receptor function of the swim bladder of fishes. J Exp Biol 14:16-19

Leis JM (1991a) The pelagic stage of reef fishes: the larval biology of coral reef fishes. In: Sale PF (ed) The ecology of fishes on coral reefs. Academic Press, San Diego, CA, p 183-230

> Leis JM (1991b) Vertical distribution of fish larvae in the Great Barrier Reef lagoon, Australia. Mar Biol 109: 157-166

Leis JM, Carson-Ewart BM (1997) In situ swimming speeds of the late pelagic larvae of some Indo-Pacific coral reef fishes. Mar Ecol Prog Ser 159:165-174

Llopiz JK, Cowen RK (2008) Precocious, selective and successful feeding of larval billfishes in the oceanic Straits of Florida. Mar Ecol Prog Ser 358:231-244

Lythgoe JN (1988) Light and vision in the aquatic environment. In: Atema J (ed) Sensory biology of aquatic animals. Springer-Verlag, New York, NY, p 57-82

MacKenzie BR, Kiorboe T (2000) Larval fish feeding and turbulence: a case for the downside. Limnol Oceanogr 45: $1-10$

Macquart-Moulin C, Castelbon C, Champalbert G, Chikhi D, Le Direach-Boursier L, Patriti G (1989) The role of barosensitivity in the control of migrations of larval and juvenile sole (Solea solea L.): influence of pressure variations on swimming activity and orientation. Rapp P-V Reun (Dan) 191:400-408

- McCutcheon FH (1966) Pressure sensitivity, reflexes, and buoyancy responses in teleosts. Anim Behav 14:204-217

> Olla BL, Davis MW, Ryer CH, Sogard SM (1996) Behavioural determinants of distribution and survival in early stages of walleye pollock, Theragra chalcogramma: a synthesis of experimental studies. Fish Oceanogr 5:167-178

Paris CB, Cowen RK (2004) Direct evidence of a biophysical retention mechanism for coral reef fish larvae. Limnol Oceanogr 49:1964-1979

> Paris CB, Chérubin LM, Cowen RK (2007) Surfing, spinning, or diving from reef to reef: effects on population connectivity. Mar Ecol Prog Ser 347:285-300

Park S, Epifanio CE, Grey EK (2004) Behavior of larval Hemi- 
grapsus sanguineus (de Haan) in response to gravity and pressure. J Exp Mar Biol Ecol 307:197-206

Pavlov DS, Sadkovskii RV, Kostin VV, Lupandin AI (2000) Experimental study of young fish distribution and behaviour under combined influence of baro-, photo- and thermo-gradients. J Fish Biol 57:69-81

Pelster B (2004) The development of the swim bladder: structure and performance. Am Fish Soc Symp 40:37-46

Pineda J, Hare JA, Sponaugle S (2007) Larval transport and dispersal in the coastal ocean and consequences for population connectivity. Oceanography 20:22-39

Qasim SZ, Rice AL, Knight Jones EW (1963) Sensitivity to pressure changes in teleosts lacking swimbladders. J Mar Biol Assoc India 5:289-293

Editorial responsibility: Alejandro Gallego, Aberdeen, UK
Rothschild BJ, Osborn TR (1988) Small-scale turbulence and plankton contact rates. J Plankton Res 10:465-474

Sale PF, Cowen RK, Danilowicz BS, Jones GP and others (2005) Critical science gaps impede use of no-take fishery reserves. Trends Ecol Evol 20:74-80

Strand E, Jorgensen C, Huse G (2005) Modelling buoyancy regulation in fishes with swimbladders: bioenergetics and behaviour. Ecol Model 185:309-327

Tytler P, Blaxter JHS (1973) Adaptation by cod and saithe to pressure changes. Neth J Sea Res 7:31-45

Werner FE, MacKenzie BR, Perry RI, Lough RG, Naimie CE, Blanton BO, Quinlan JA (2001) Larval trophodynamics, turbulence, and drift on Georges Bank: a sensitivity analysis of cod and haddock. Sci Mar 65:99-115

Submitted: November 6, 2007; Accepted: May 19, 2008

Proofs received from author(s): September 2, 2008 